\title{
Comparison of molecular structure of alkali metal ortho substituted benzoates
}

\author{
R. Świsłocka \\ Department of Chemistry, Biatystok Technical University, Zamenhofa 29, 15-435 Biatystok, Poland \\ Tel.: +4808574697 96; E-mail: r.swislocka@pb.edu.pl
}

\begin{abstract}
The influence of the amino-, nitro-, methoxy-, hydroxy- and chloro-substituents in the ortho position towards the carboxylic group as well as alkali metal on molecular structure of benzoates was estimated. Optimized geometrical structures were calculated by B3LYP/6-311++G** method. Experimental FT-IR, FT-Raman and NMR spectra of the title compounds were recorded and analyzed. Data of chemical shifts in ${ }^{1} \mathrm{H}$ and ${ }^{13} \mathrm{C}$ NMR as well as wavenumbers and intensities in IR and Raman spectra of studied benzoate derivatives were analyzed in comparison with benzoic acid and with alkali metal benzoates. Keywords: o-amino-, o-nitro-, o-methoxy-, o-hydroxy-, o-chlorobenzoates, FT-IR, FT-Raman, NMR, DFT, molecular structure
\end{abstract}

\section{Introduction}

Benzoic acid derivatives represent a wide group of aromatic ligands, which are constituent parts of enzymes and other biologically important molecules. Their properties and electronic charge distribution in the ring are subjects of several works [3,4]. The aim of this paper is to show the effect of different substituents as well as alkali metals on the molecular structure of benzoates. FT-IR, FT-Raman, ${ }^{1} \mathrm{H}$ and ${ }^{13} \mathrm{C}$ NMR measurements as well as quantum chemical calculations were used in this research. The present work is a continuation of the recent reports [2,5-7].

\section{Experimental section}

The alkali metal benzoates substituted in ortho position were prepared as described in the literature [2,5-7]. The IR spectra were recorded with the EQUINOX 55, BRUKER FT-IR spectrometer within the range $4000-400 \mathrm{~cm}^{-1}$. Samples in the solid state were measured in $\mathrm{KBr}$ matrix. Pellets were obtained with a hydraulic press under 739 MPa pressure. Raman spectra of solid samples in capillary tubes were recorded in the range of 4000-400 $\mathrm{cm}^{-1}$ with a FT-Raman accessory of the Perkin Elmer System 2000. The resolution of spectrometer was $1 \mathrm{~cm}^{-1}$. The NMR spectra of $\mathrm{D}_{2} \mathrm{O}$ saturated solution were recorded with the NMR AC $200 \mathrm{~F}$, Bruker unit at room temperature. TMS was used as an internal reference.

The density functional (DFT) hybrid method B3LYP/6-311++ $\mathrm{G}^{* *}$ was used to calculate optimized geometrical structures. All theoretical calculations were performed using the Gaussian 98W (v. 5.4) package of programs [1] running on a PC computer. 


\section{Results and discussion}

\subsection{Calculated structure}

The bond lengths and the angles between bonds in studied molecules were presented in Table 1 . The largest differences between bonds as well as angles in the ring increase in the following series: $\mathrm{H}<\mathrm{NO}_{2}<\mathrm{Cl}<\mathrm{OCH}_{3}<\mathrm{NH}_{2}$. It indicates that these substituents perturb the aromatic ring in this order.

\subsection{Vibrational spectra}

The experimental IR bands of studied compounds were presented in Fig. 1 (assignment was supported by Varsányi [8]). The FT-IR and Raman spectra of substituted benzoates contain more bands in comparison with unsubstituted one, because some bands connected with substituents appear. Moreover, some changes in bands of aromatic ring and carboxyl anion are also observed. FT-IR spectra of sodium ohydroxy-, o-methoxy-, o-nitro- and o-aminobenzoates are shown in Fig. 1. An increase of wavenumbers of $19 \mathrm{~b}-\nu(\mathrm{CC})$ band connected with aromatic ring in IR spectra is observed in the series of ortho substituted sodium benzoates: $\mathrm{H}<\mathrm{NO}_{2}<\mathrm{Cl}<\mathrm{NH}_{2}<\mathrm{OH}<\mathrm{OCH}_{3}$. In Raman spectra the order is similar: $\mathrm{H}<\mathrm{NO}_{2}<\mathrm{Cl}<\mathrm{OH}<\mathrm{NH}_{2}=\mathrm{OCH}_{3}$. For $18 \mathrm{a}-\beta(\mathrm{CH})$ band in IR and Raman spectra the increase is observed in following series: $\mathrm{H}<\mathrm{NO}_{2}<\mathrm{OCH}_{3}<\mathrm{Cl}<\mathrm{OH}$. However the decrease of wavenumbers is observed for $19 \mathrm{a}-\nu(\mathrm{CC})$ and $18 \mathrm{~b}-\beta(\mathrm{CH})$ bands. In the case of bands connected with $\mathrm{COO}^{-}$anion the wavenumbers of $\nu_{\text {as }}$ band increase in comparison with unsubstituted benzoate (except for o-aminobenzoate), but for $\nu_{\mathrm{s}}$ the decrease of wavenumbers is noticed. The values of $\Delta \nu(\mathrm{COO})$ in IR spectra calculated for sodium ortho substituted (amino-, nitro-, methoxy-, chloro- and hydroxy-) benzoates amount to 140,169,170, 189 and $193 \mathrm{~cm}^{-1}$, respectively. They are higher than for unsubstituted one $\left(141 \mathrm{~cm}^{-1}\right)$, except for o-aminobenzoate which is almost equal. They increase in the following order: $\mathrm{NH}_{2} \approx \mathrm{H}<\mathrm{NO}_{2}<\mathrm{OCH}_{3}<\mathrm{Cl}<\mathrm{OH}$. The largest values of $\Delta \nu(\mathrm{COO})$ for o-hydoxybenzoates could be explained by hydrogen bonds exist between carboxylate and hydroxyl groups.

\subsection{NMR spectra}

The chemical shifts of protons and carbons express the effect of the substituent on the electronic charge density around those atoms. The influence of substituents on the electronic charge density around atoms in sodium benzoate molecule is noticed. The changes of chemical shifts are presented in Fig. 2. The substituent involves an increase in chemical shift values for C2, C4 and C6 carbon atoms in comparison with unsubstituted sodium benzoate. It indicates a decrease in electronic charge density around the nuclei and a decrease in the screening effect. In the case of $\mathrm{C} 3$ carbon atom a decrease in chemical shift values is observed for nitro, amino, and methoxy o-substituted benzoates. In the case of o-chlorobenzoates the least changes are noticed. The higher changes are observed for amino and nitro groups because of their strong electron-donating $\left(\mathrm{NH}_{2}\right)$ and electron-withdrawing $\left(\mathrm{NO}_{2}\right)$ properties. The highest changes of chemical shifts of $\mathrm{C} 2$ atom are noticed for methoxy group, which could be explained by steric barrier.

A decrease in chemical shifts of all protons in substituted benzoates (except from nitrobenzoate) in comparison with sodium benzoate is observed. It points at an increase in the screening of the protons as a consequence of decrease of the circular current. It is evidence that those substituents perturb the electronic charge distribution in the molecule. Chemical shifts for $\mathrm{H} 3-\mathrm{H} 5$ protons decrease in the series $\mathrm{NO}_{2}>\mathrm{H}>\mathrm{Cl}>\mathrm{OCH}_{3}>\mathrm{NH}_{2}$. For $\mathrm{H} 6$ atom a decrease in chemical shifts is observed in all substituted benzoates $\left(\mathrm{H}>\mathrm{NH}_{2}>\mathrm{NO}_{2}>\mathrm{Cl}>\mathrm{OCH}_{3}\right)$. 
Table 1

The bond lengths and angles calculated for sodium benzoates (B3LYP/6-311++G**)

\begin{tabular}{|c|c|c|c|c|c|c|}
\hline Atoms $^{1}$ & Benzoate & $\begin{array}{l}\text { o-amino- } \\
\text { benzoate }\end{array}$ & $\begin{array}{l}\text { o-chloro- } \\
\text { benzoate }\end{array}$ & $\begin{array}{c}\text { o-hydroxy- } \\
\text { benzoate }\end{array}$ & $\begin{array}{c}\text { o-methoxy- } \\
\text { benzoate }\end{array}$ & $\begin{array}{l}\text { o-nitro- } \\
\text { benzoate }\end{array}$ \\
\hline \multicolumn{7}{|l|}{ Bond length } \\
\hline $\mathrm{C} 1-\mathrm{C} 2$ & 1.397 & 1.421 & 1.402 & 1.410 & 1.414 & 1.397 \\
\hline $\mathrm{C} 2-\mathrm{C} 3$ & 1.394 & 1.412 & 1.395 & 1.402 & 1.401 & 1.390 \\
\hline $\mathrm{C} 3-\mathrm{C} 4$ & 1.394 & 1.384 & 1.391 & 1.389 & 1.394 & 1.391 \\
\hline $\mathrm{C} 4-\mathrm{C} 5$ & 1.394 & 1.400 & 1.394 & 1.394 & 1.390 & 1.394 \\
\hline C5-C6 & 1.394 & 1.386 & 1.389 & 1.389 & 1.393 & 1.393 \\
\hline $\mathrm{C} 6-\mathrm{C} 1$ & 1.397 & 1.403 & 1.403 & 1.402 & 1.397 & 1.396 \\
\hline $\mathrm{C} 7-\mathrm{C} 1$ & 1.511 & 1.496 & 1.515 & 1.512 & 1.512 & 1.514 \\
\hline O9-C7 & 1.266 & 1.284 & 1.262 & 1.264 & 1.273 & 1.262 \\
\hline C7-O10 & 1.266 & 1.267 & 1.269 & 1.274 & 1.264 & 1.261 \\
\hline Na11-O9 & 2.216 & 2.198 & 2.211 & 2.203 & 2.205 & 2.237 \\
\hline $\mathrm{Na} 11-\mathrm{O} 10$ & 2.218 & 2.198 & 2.216 & 2.206 & 2.205 & 2.215 \\
\hline$C 2-X^{2}$ & 1.083 & 1.372 & 1.759 & 1.362 & 1.359 & 1.479 \\
\hline C3-H3 & 1.085 & 1.086 & 1.083 & 1.087 & 1.081 & 1.082 \\
\hline C4-H4 & 1.084 & 1.085 & 1.084 & 1.085 & 1.085 & 1.083 \\
\hline C5-H5 & 1.085 & 1.084 & 1.084 & 1.084 & 1.084 & 1.084 \\
\hline C6-H6 & 1.084 & 1.083 & 1.083 & 1.082 & 1.083 & 1.083 \\
\hline \multicolumn{7}{|l|}{ Bond angle } \\
\hline C7-C1-C6 & 120.38 & 118.06 & 117.15 & 117.67 & 117.62 & 119.3 \\
\hline $\mathrm{C} 2-\mathrm{C} 1-\mathrm{C} 7$ & 120.38 & 122.97 & 125.40 & 124.53 & 123.97 & 123.2 \\
\hline $\mathrm{O} 10-\mathrm{C} 7-\mathrm{C} 1$ & 118.04 & 118.93 & 116.91 & 117.00 & 119.75 & 117.2 \\
\hline $\mathrm{C} 1-\mathrm{C} 6-\mathrm{C} 5$ & 120.36 & 122.13 & 121.95 & 122.50 & 122.06 & 121.1 \\
\hline C6-C5-C4 & 120.22 & 118.73 & 119.50 & 119.03 & 118.98 & 120.3 \\
\hline $\mathrm{C} 5-\mathrm{C} 4-\mathrm{C} 3$ & 119.58 & 120.55 & 119.84 & 119.84 & 120.40 & 119.7 \\
\hline $\mathrm{C} 4-\mathrm{C} 3-\mathrm{C} 2$ & 120.22 & 121.35 & 120.16 & 121.13 & 120.53 & 119.1 \\
\hline $\mathrm{C} 6-\mathrm{C} 1-\mathrm{C} 2$ & 119.25 & 118.97 & 117.45 & 117.80 & 118.40 & 117.3 \\
\hline $\mathrm{C} 1-\mathrm{C} 2-\mathrm{C} 3$ & 120.36 & 118.26 & 121.08 & 119.71 & 119.60 & 122.5 \\
\hline Na11-O9-C7 & 87.73 & 89.21 & 88.06 & 88.26 & 88.05 & 86.2 \\
\hline O9-C7-C1 & 118.08 & 119.40 & 119.33 & 119.93 & 119.75 & 117.7 \\
\hline H6-C6-C5 & 119.92 & 120.92 & 120.91 & 120.98 & 120.76 & 120.7 \\
\hline $\mathrm{H} 5-\mathrm{C} 5-\mathrm{C} 4$ & 120.05 & 120.65 & 120.42 & 120.58 & 120.66 & 120.0 \\
\hline $\mathrm{H} 4-\mathrm{C} 4-\mathrm{C} 3$ & 120.21 & 119.31 & 119.54 & 119.56 & 119.18 & 119.8 \\
\hline $\mathrm{H} 3-\mathrm{C} 3-\mathrm{C} 2$ & 119.73 & 118.63 & 119.16 & 118.93 & 120.36 & 119.4 \\
\hline $\mathrm{X}-\mathrm{C} 2-\mathrm{C} 1$ & 118.46 & 124.00 & 122.65 & 120.62 & 117.74 & 120.7 \\
\hline
\end{tabular}

Note: ${ }^{1}$ Atoms numbers as following figure; ${ }^{2} \mathrm{X}=\mathrm{H}, \mathrm{Cl}, \mathrm{NH}_{2}, \mathrm{NO}_{2}, \mathrm{OH}, \mathrm{OCH}_{3}$.

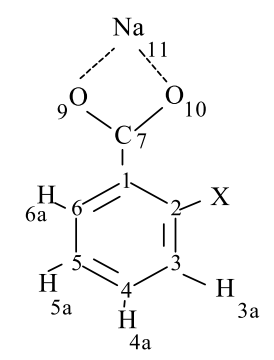




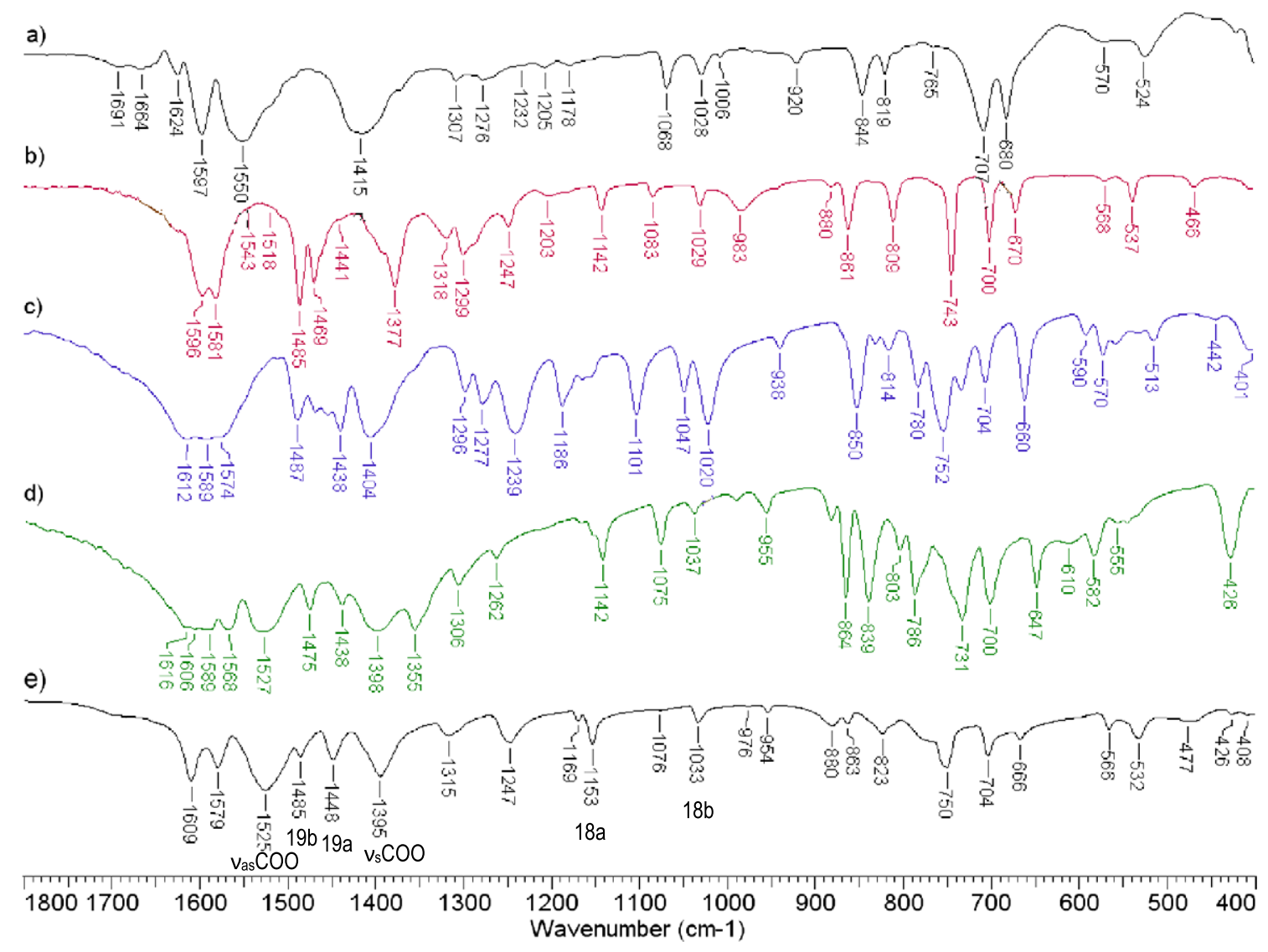

Fig. 1. FT-IR spectra of ortho substituted sodium benzoates: (a) benzoate-; (b) hydroxy-; (c) methoxy-; (d) nitro-; (e) aminobenzoate.
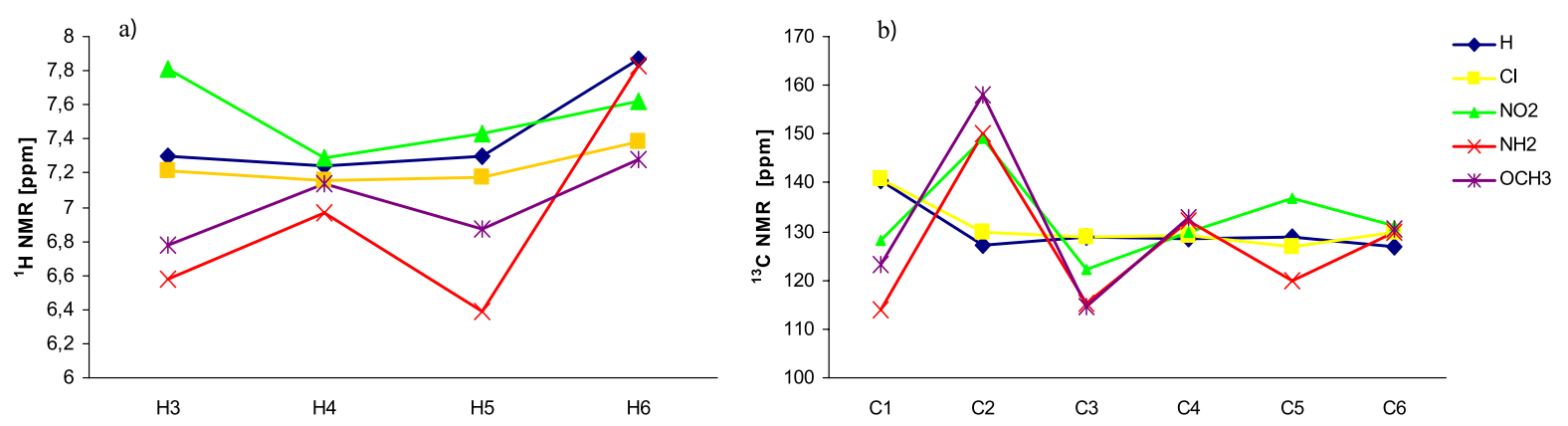

Fig. 2. The changes of ${ }^{1} \mathrm{H}$ NMR (a) and ${ }^{13} \mathrm{C}$ NMR (b) chemical shifts in ortho substituted sodium benzoates.

\section{Conclusions}

The effect of different substituents as well as alkali metals on the molecular structure of benzoates is noticed:

- The variety of the bond lengths and the angles in the ring increases in the following order: $\mathrm{H}<$ 
$\mathrm{NO}_{2}<\mathrm{Cl}<\mathrm{OCH}_{3}<\mathrm{NH}_{2}$. It indicates that these substituents perturb the aromatic ring in this order.

- The wavenumbers of $\nu_{\mathrm{as}}\left(\mathrm{COO}^{-}\right)$asymmetric stretching vibration increase in comparison with sodium unsubstituted benzoate (except for aminobenzoate).

- The substituent involves an increase in chemical shifts of carbons. The higher changes are observed for amino and nitro substituents because of their strong electron-donating $\left(\mathrm{NH}_{2}\right)$ and electronwithdrawing $\left(\mathrm{NO}_{2}\right)$ properties. The least changes are observed in the case o-chlorobenzoates.

- A decrease in chemical shifts of all protons in substituted benzoates (except from nitrobenzoate) is observed in comparison with unsubstituted one. It is evidence that those substituents perturb the electronic charge distribution in the molecule.

\section{Acknowledgement}

Presented work was supported by The Scientific Research Committee in Poland (theme No. G/WBIIŚ/21/08).

\section{References}

[1] M.J. Frisch, G.W. Trucks, H.B. Schlegel, G.E. Scuseria, M.A. Robb, J.R. Cheeseman, V.G. Zakrzewski, J.A. Montgomery, R.E. Stratmann, J.C. Burant, S. Dapprich, J.M. Millam, A.D. Daniels, K.N. Kudin, M.C. Strain, O. Farkas, J. Tomasi, V. Barone, M. Cossi, R. Cammi, B. Mennucci, C. Pomelli, C. Adamo, S. Clifford, J. Ochterski, G.A. Petersson, P.Y. Ayala, Q. Cui, K. Morokuma, D.K. Malick, A.D. Rabuck, K. Raghavachari, J.B. Foresman, J. Cioslowski, J.V. Ortiz, B.B. Stefanov, G. Liu, A. Liashenko, P. Piskorz, I. Komaromi, R. Gomperts, R.L. Martin, D.J. Fox, T. Keith, M.A. AlLaham, C.Y. Peng, A. Nanayakkara, C. Gonzalez, M. Challacombe, P.M.W. Gill, B.G. Johnson, W. Chen, M.W. Wong, J.L. Andres, M. Head-Gordon, E.S. Replogle and J.A. Pople, Gaussian 98 (Revision A.11.2), Gaussian, Inc., Pittsburgh, PA, 1998.

[2] M. Kalinowska, R. Świsłocka and W. Lewandowski, J. Mol. Struct. 792-793 (2006), 130-138.

[3] W. Lewandowski, M. Kalinowska and H. Lewandowska, Inorg. Chim. Acta 358 (2005), 2155-2166.

[4] W. Lewandowski, M. Kalinowska and H. Lewandowska, J. Inorg. Biochem. 99 (2005), 1407-1423.

[5] W. Lewandowski, B. Dasiewicz, P. Koczoń, J. Skierski, K. Dobrosz-Teperek, R. Swisłocka, L. Fuks, W. Priebe and A.P. Mazurek, J. Mol. Struct. 604 (2002), 189-193.

[6] M. Samsonowicz, R. Świsłocka, E. Regulska and W. Lewandowski, J. Mol. Struct. 887 (2008), 220-228.

[7] R. Świsłocka, M. Samsonowicz, E. Regulska and W. Lewandowski, J. Mol. Struct. 834-836 (2007), 389-398.

[8] G. Varsányi, Assignments for Vibrational Spectra of 700 Benzene Derivatives, Akademiai Kiado, Budapest, Hungary, 1973. 


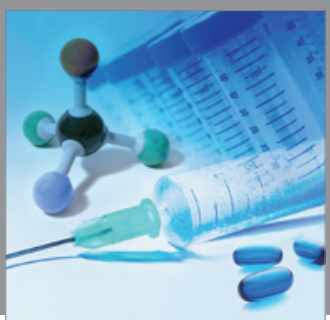

International Journal of

Medicinal Chemistry

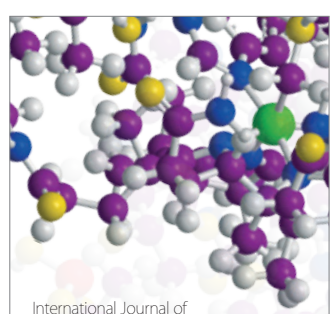

Carbohydrate Chemistry

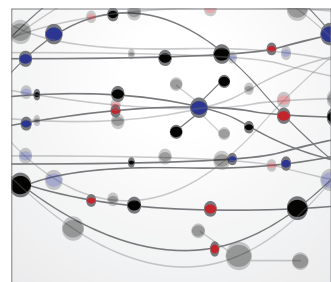

The Scientific World Journal
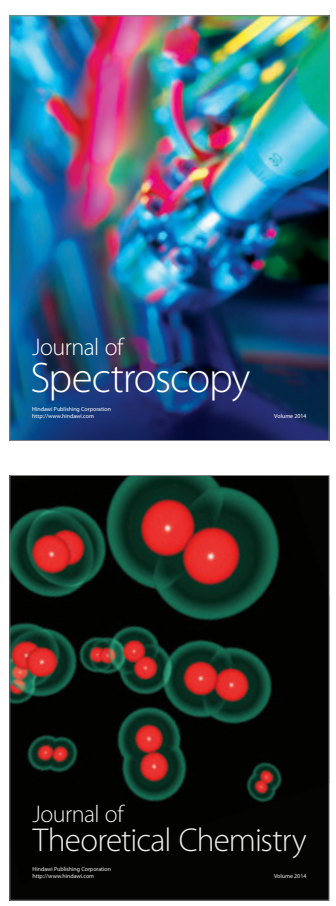
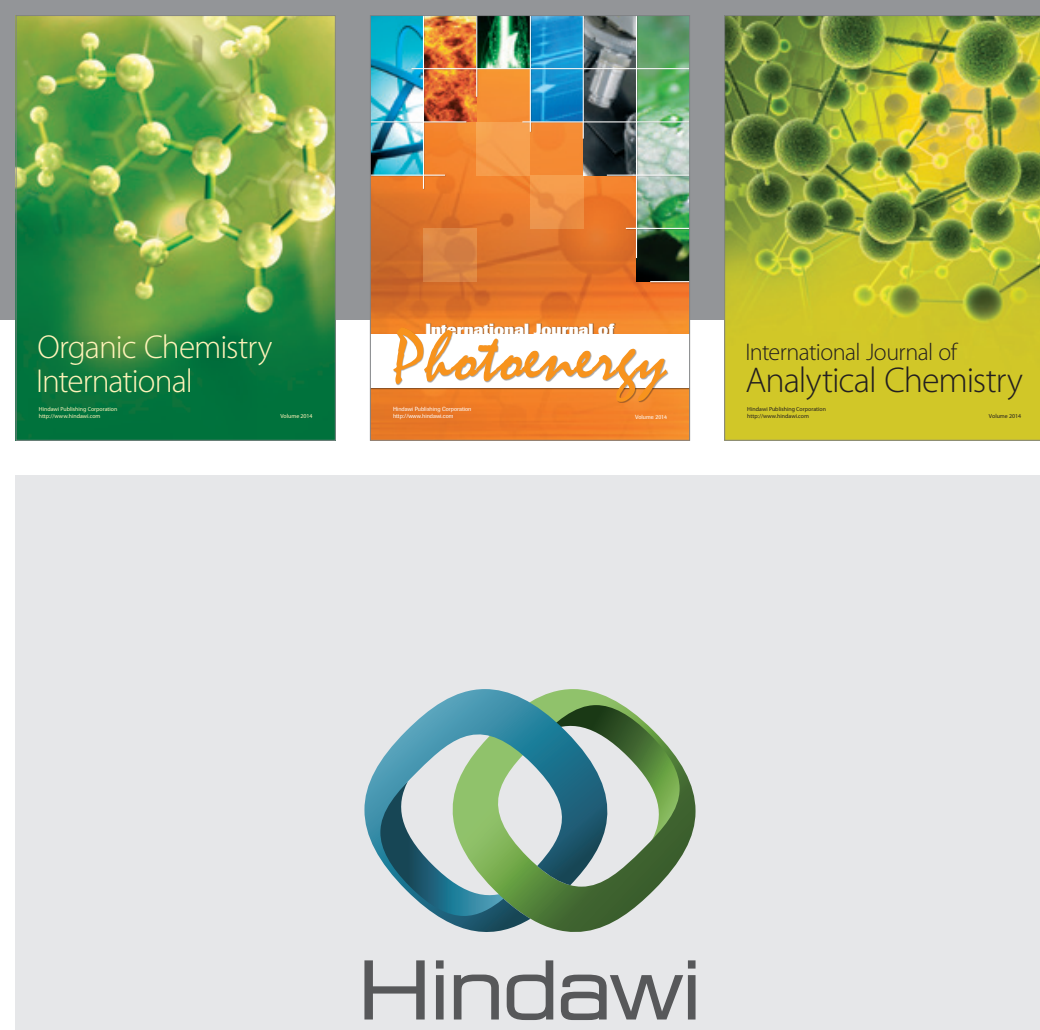

Submit your manuscripts at

http://www.hindawi.com
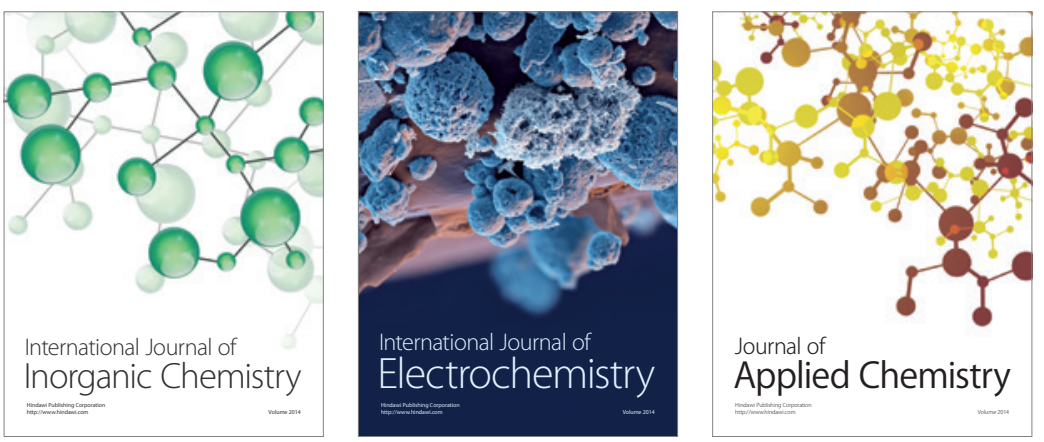

Journal of

Applied Chemistry
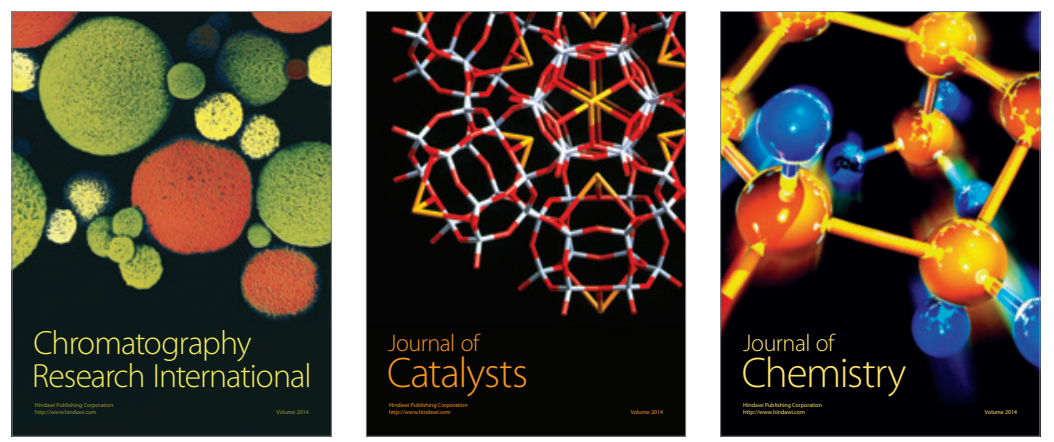
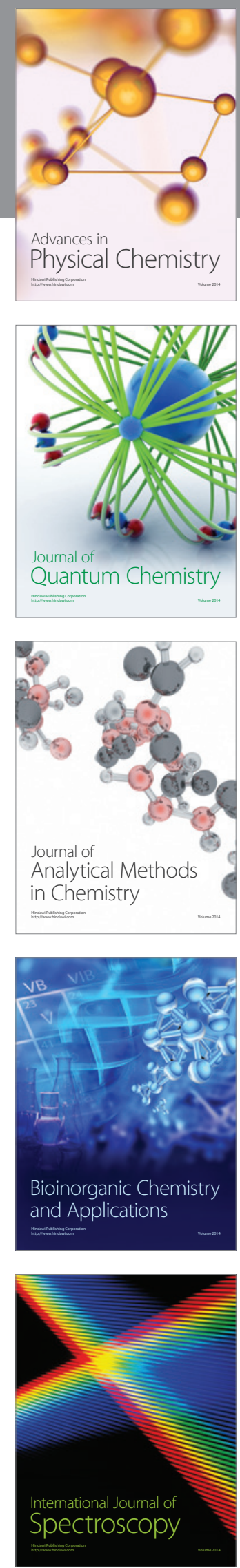